\title{
EFEKTIVITAS STRATEGI PEMBERIAN UMPAN BALIK TERHADAP KINERJA PRAKTIKUM MAHASISWA D-3 JURUSAN TEKNIK ELEKTRONIKA
}

\author{
Sapto Haryoko \\ FT Universitas Negeri Makassar (e-mail: saptoharyoko@yahoo.com; \\ HP. 081578844909)
}

\begin{abstract}
Effectiveness of the Feedback Providing Strategies on the Practicum Performance of the Students of the Diploma Three (D-3) of the Electronic Engineering Department. This study aims to investigate the effectiveness of the feedback providing strategies (immediate feedback and delayed feedback) on students' performance in the Electronics lab course. This study was an experiment employed a posttest-only control group design. The subjects were students of the Diploma Three (D-3) Program of the Electronic Engineering Department of FT UNM, divided into two treatment groups. Group A, consisting of 20 students, received the treatment of the immediate feedback and Group B, consisting of 19 students, received the treatment of delayed feedback. The data on the students' mastery of lab materials were collected through observations using a performance assessment form. The data were analyzed using the t-test. The results showed that the practicum performance of the students receiving immediate feedback was better than that of the students receiving delayed feedback.
\end{abstract}

Keywords: immediate feedback, delayed feedback, students' practicum performance

\section{PENDAHULUAN}

Seiring dengan perluasan mandat IKIP Ujung Pandang menjadi Universitas Negeri Makassar, pada tahun 1997 Fakultas Teknik Universitas Negeri Makassar menyelenggarakan program Diploma Tiga (D-3), yang salah satu di antaranya adalah Jurusan Teknik Elektronika. Sebagai pendidikan yang berbasis akademik dan profesional, pendidikan program Diploma Tiga (D-3) lebih menekankan pada kompetensi untuk menangani pekerjaan dalam bidang tertentu. Sebagai calon tenaga kerja yang memiliki kewenangan ahli madya, Program D-3 diharapkan akan menghasilkan lulusan yang mempunyai kesiapan untuk terjun kelapangan kerja sesuai dengan bidang keahliannya. Namun demikian, harapan sering tidak sejalan dengan kenyataan. Sudah menjadi sorotan masyarakat bahwa lulusan lembaga pendidikan formal masih kesulitan untuk mendapatkan pekerjaan yang relevan karena keterampilan yang dimiliki belum sesuai dengan yang dibutuhkan oleh perusahaan atau pi- 
hak industri. Lulusan pendidikan formal hampir $60 \%$ sampai $70 \%$ memerlukan latihan khusus untuk membekali mereka sehingga memiliki kemampuan yang lebih memadai untuk siap terjun ke dunia kerja (BPS, 2005).

Untuk menghasilkan mahasiswa sebagai calon tenaga kerja berkualitas, dalam struktur kurikulum Program Diploma Tiga (D-3) Jurusan Teknik Elektronika (JTA) FT UNM ditempatkan Mata kuliah Praktik Elektronika sebagai bagian penting (mata kuliah wajib) yang harus dikuasai oleh seorang mahasiswa calon tenaga ahli bidang elektronika. Keberadaan mata kuliah tersebut dimaksudkan untuk membekali mahasiswa dengan kompetensi bidang studi (profesional) agar kelak para mahasiswa memiliki kemampuan yang memadai dalam menjalankan tugas sebagai tenaga kerja tingkat madia di bidang teknik elektronika. Sebagai mata kuliah utama (inti) dalam bidang keahlian elektronika, mata kuliah Praktek Elektronika memuat berbagai kompetensi yang harus dikuasai oleh mahasiswa sebagai bekal bagi mereka calon tenaga kerja bidang teknik elektronika agar kelak mereka memiliki kompetensi yang memadai dalam bidang studi yang ditekuni.

Berdasarkan data yang diperoleh pada arsip Jurusan Teknik Elektronika FT-UNM, pada tahun ajaran 2008/ 2009, hanya sekitar $12 \%$ yang mendapat nilai $\mathrm{A}, 13 \%$ nilai $\mathrm{B}, 43 \%$ nilai $\mathrm{C}$, dan $32 \%$ yang tidak lulus (nilai $D$ atau E). Lama studi mahasiswa pada jurusan ini rata-rata lima tahun dua bulan. Hanya sebagian kecil mahasiswa (10\%) yang dapat menyelesaikan studi tepat waktu (empat tahun). Fakta tersebut mengindikasikan masih lemahnya penguasaan mahasiswa di bidang keahlian elektronika. Setelah dilakukan kajian lebih mendalam, diduga salah satu penyebabnya berkaitan dengan metode atau strategi pembelajaran yang kurang efektif. Indikasi ini terlihat dari kurangnya komunikasi dan partisipasiaktif mahasiswa selama kegiatan praktikum berlangsung. Mahasiswa kurang mengajukan pertanyaan meskipun menghadapi kesulitan/kendala dalam kegiatan praktikum sehingga dosen/instruktur tidak mengetahui masalah yang dihadapi oleh mahasiswa selama kegiatan praktikum.

Kenyataan di atas mengisyaratkan perlunya upaya-upaya yang lebih inovatif dan kreatif dari dosen pengasuh mata kuliah praktikum untuk meningkatkan kualitas proses dan hasil pembelajaran di laboratorium, sehingga dengan demikian mahasiswa dapat menguasai secara memadai kompetenasi yang menjadi tuntutan kurikulum. Ada satu hal yang dalam proses pendidikan atau pembelajaran di sekolah yang merupakan satu sisi terpenting untuk mendapatkan hasil maksimal dari prestasi belajar siswa/ mahasiswa serta menumbuhkan sikap positif terhadap proses belajarnya, yakni persoalan feedback (umpan balik) dalam pembelajaran. Dalam ilmu komunikasi, umpan balik dianggap sebagai faktor terpenting dalam menentukan keberhasilan pesan yang ingin disampaikan kepada penerima pesan. Umpan balik kaitannya dalam prosespembelajaran adalah bentuk komunikasi antara guru dengan siswa, 
siswa dengan siswa, maupun siswa dengan dirinya sendiri yang terintegrasi secara menyeluruh.

Dalam kaitan dengan pembelajaran, Irons (2008) mengemukakan bahwa umpan balik adalah setiap informasi, proses atau aktivitas yang dilakukan untuk mempercepat siswa belajar yang didasarkan pada komentar-komentar berkaitan dengan hasil penilaian perkembangan siswa. Sementara itu, Tulgan (1999) berpendapat bahwa umpan balik adalah suatu bentuk komunikasi yang reaktif, yang merupakan respons terhadap berbagai jenis tindakan atau masukan. Umpan balik digambarkan sebagai suatu proses mengidentifikasi kesenjangan antara kinerja yang diinginkan dan yang nyata, memberikan cara bagaimana siswa data menyelesaikan atau menghilangkan kesenjangan tersebut (Joghin, 2009).

Dosen/guru biasanya memberikan umpan balik terhadap tugas, latihan, ulangan harian, upaya belajar, penguasaan suatu keterampilan, dan sebagainya, yang telah diupayakan oleh siswa/mahasiswa. Untuk memberikan umpan balik, dosen dapat melakukan baik secara verbal maupun nonverbal. Umpan balik dapat bersifat reward terhadap hasil belajar yang mereka lakukan/capai dengan baik. Bisa pula berupa kritikan yang bersifat membangun motivasi belajar dan perbaikan proses atau pencapaian hasil belajar tadi. Untuk memberikan umpan balik yang produktif, pemberian umpan balik perlu disertai informasi yang membimbing siswa dalam mengkonstruksi pengetahuan. Karena umpan balik tidak akan begitu saja merubah atau meningkatkan respon siswa dalam proses pembelajaran. Salah satu prinsip penggunaan umpan balik adalah diberikan sesegera mungkin oleh dosen/guru kepada siswa. Memberikan umpan balik tepat waktu dan bermakna bagi para siswa mempunyai potensi untuk menjadi proses belajar mengajar menjadi efektif (Stevens \& Levi, 2005).

Manfaat dari pemberian umpan balik dapat menumbuhkan rasa percaya diri mahasiswa. Mereka dapat menyadari kekuatan dan kelemahan dirinya sebagai akibat adanya umpan balik yang diterima. Bloxham dan Boyd (2007) mengemukakan bahwa prinsip kunci umpan balik adalah bahwa umpan balik akan berguna bila menginformasikan kepada siswa tentang cara-cara untuk memperbaiki kinerja mereka. Umpan balik yang bermakna dapat mengembangkan kepercayaan diri dan meningkatkan motivasi mahasiswa. Dalam kaitan ini, Allin \& Turnock (2007) mengemukakan bahwa umpan balik yang diberikan harus jelas, spesifik, bersifat personal, dan jujur. Oleh karena itu, beberapa hal yang perlu diperhatikan dalam memberikan umpan balik yang berkualitas bagi mahasiswa antara lain: terlebih dahulu meminta mahasiswa untuk menilai dirinya sendiri, memberi pujian sebelum mengeritik, batasi apa yang ingin dibahas, berkonsentrasi pada apa yang bisa diubah/diperbaiki, dan beri mahasiswa waktu untuk berpikir dan menanggapi. 
Pada kegiatan pembelajaran di laboratorium, umpan balik merupakan komponen yang sangat penting bagikeberhasilan belajar (praktik) mahasiswa. Umpan balik dapat disampaikan secara verbal (lisan) maupun tertulis. Pemberian umpan balik dapat dilakukan segera setelah kegiatan praktik berlangsung tanpa harus menunggu kegiatan praktik yang berikutnya (immediate feedback), atau dapat pula diberikan pada suatu tenggang waktu tertentu setelah siswa melalui beberapa kali kegiatan praktik (delay feedback).

Telah banyak hasil penelitian dari beberapa pakar yang menggambarkan korelasi positif antara keselarasan prestasi belajar siswa dengan penggunaan umpan balik yang efektif. Keunggulan dari umpan balik langsung telah menunjukkan dengan tegas untuk meningkatkan penguasaan bahan verbal maupun kemahiran motor keterampilan (Anderson, Magill, \& Seklya, 2001). Kulik dan Kulik (1988) melaporkan bahwa umpan balik langsung lebih efektif daripada umpan balik tertunda untuk diterapkan, tetapi tidak pada kegiatan di laboratorium. Pendukung umpan balik langsung berteori bahwa informasi koreksi yang diberikan sebelumnya, besar kemungkinanakan menghasilkan retensi yang efisien (Phye \& Andre, 1989). Menurut Epstein, Epstein, \& Brosvic, (2001) jika tidak ada umpan balik yang bersifat korektif, mahasiswa mungkin akan bertanya-tanya apakah respons yang diberikan benar atau salah. Suatu prosedur pembelajaran di laboratorium yang tidak menggunakan umpan balik langsung mungkin dapat menyebabkan kesalahpahaman dari pebelajar. Umpan balik segera (langsung) dapat menjadi gangguan bagi mahasiswa ketika harus melakukan berulang untuk memperbaiki kekurangan atau kesalahan. Mutch (2003) berpendapat bahwa umpan balik bisa melahirkan kesalahpahaman dan diabaikan.

Berdasarkan review beberapa hasil penelitian yang dilakukan Dihoff et.al (2010), disimpulkan bahwa pemberian umpan balik segera (langsung) dapat memperbaiki pengelolaan kelas dan meningkatkan interaksi mahasiswa dalam kelas, serta meningkatkan kinerja siswa sekolah umum dan mahasiswa. Dari hasil penelitian mereka menyimpulkan bahwa umpan balik langsung yang dikuti dengan proses jawaban-sampai-benar tidak hanya yang paling efektif tetapi juga yang paling disukai. Dalam studi yang terkait, Robin (Dihoff, 2010) melaporkan bahwa umpan balik langsung dan tertunda mempunyai tingkat keefektifan yang sama. Umpan balik segera dan tertunda telah meningkatkan kinerja mahasiswa pascasarjana, dan kinerja mahasiswa pada tes kemampuan umum. (Beck\& Lindsey, 1979). Walaupun umpan balik tertunda (delay feedback) belum didukung dalam beberapa penelitian, namun Newman, Williams, \& Hiller (1974) menyatakan bahwa umpan balik tertunda sama efektifnya dengan umpan balik langsung.

Beberapa pendapatdiatas tampaknya masih terjadi perbedaan pendapat tentang efek dari strategi pemberian 
umpan balik (umpan balik langsung dan tertunda) terhadap kualitas proses dan hasil pembelajaran. Robin (Dihoff, 2010) menyatakan bahwa walaupun ada kesepakatan yang cukup bahwa belajar adalah difasilitasi oleh umpan balik, namun dipertanyakan seperti apa jenis umpan balik yang paling efektif. Oleh karena itu, peneliti tertarik untuk menguji efektivitas strategi pemberian umpan balik pada kondisi kegiatan praktikum mahasiswa, khususnya dalam pembelajaran praktikum elektronika pada juruan Tekni Elektronika FT UNM.

Berdasarkan pemaparan di atas, dapat disimpulkan bahwa umpan balik merupakan suatu bagian penting dalam kegiatan belajar-mengajar. Umpan balik sangat mempengaruhi motivasi belajar siswa. Pemberian umpan balik sangat tepat digunakan dalam berbagai pembelajaran guna meningkatkan kualitas proses dan hasil pembelajaran, termasuk pada pembelajaran mata kuliah Praktik Elektronika. Jadi, salah satu upaya yang diharapkan dapat meningkatkan kemampuan penguasaan mahasiswa terhadap materi kuliah Praktikum adalah dengan memberikan umpan balik dan tutorial secara teratur bagi mahasiswa.

Sebagai bentuk perlakuan (treatment) dalam penelitian ini, mahasiswa dibagi ke dalam dua kelompok perlakuan, yakni kelompok mahasiswa yang diberi umpan balik langsung (immediate feedback) dan kelompok mahasiswa yang diberi umpan balik tertunda (delay feedback). Sehubungan dengan penerapan strategi umpan balik sebagai bentuk perlakuan (treatment) dalam pembelajaran Praktikum Elektronika, lingkup penelitian ini dibatasi pada ketercapaian proses dan hasil belajar matakuliah Praktikum Elektronika yang berkualitas sesuai dengan target yang ditetapkan sebagai dampak dari perlakuan yang dikembangkan dalam penelitian ini. Oleh karena itu, indikator keberhasilan pembelajaran sebagai akibat dari penerapan strategi umpan balik adalah kinerja praktikum mahasiswa dalam mata kuliah Praktik Elektronika yang diukur melalui prosesdur kerja dan keberhasilan menyelesaikan tugas dengan tepat dalam waktu yang ditentukan.

Dengan demikian, penelitian ini dimaksudkan untuk mengetahui pengaruh variasi strategi pemberian umpan balik terhadap kinerja praktikum mahasiswa, khususnya pada kegiatan praktik elektronika yang disajikan selama satu semester akademik. Umpan balik diberikan setelah setiap akhir praktikum, atau setelah penundaan selama satu minggu atau sampai pada kegiatan praktikum berikutnya. Mahasiswa mengerjakan setiap tugas selama satu semester dengan menggunakan umpan balik masing-masing dan kemudian diberikan ujian akhir. Prosedur ini memungkinkan untuk menentukan dampak dari variasi umpan balik yang diberikan (langsung atau tertunda). Untuk mengukur tingkat kinerja mahasiswa, dilakukan ujian yang komprehensip pada akhir pemberian perlakuan. Oleh karena itu, pada penelitian ini dirumuskan hipotesis, yakni kelompok mahasiswa 
yang diberi umpan balik langsung memiliki kinerja praktikum yang lebih baik dibandingkan kelompok mahasiswa yang diberi umpan balik tertunda pada matakuliah Praktik Elektronika.

\section{METODE}

Penelitian ini merupakan penelitian eksperimen yang menggunakan Posttest-Only Control Design. Subjek penelitian adalah mahasiswa Program Diploma Tiga (D-3) Jurusan Teknik Elektronika FT UNM yang berjumlah 39 orang, dan sedang memprogramkan mata kuliah Praktik Elektronika. Subjek penelitian dibagi ke dalam dua kelompok eksperimen, yakni kelompok mahasiswa yang diberi umpan balik langsung (immediate feedback) sebanyak 20 orang (Kelompok A), dan kelompok mahasiswa yang diberi umpan balik tertunda (delay feedback) sebanyak 19 orang (Kelompok B).

Pemberian umpan balik (immediate feedback) secara langsung adalah pemberian umpan balik tentang informasi prosedur dan hasil kerja terkait kinerja praktik terdahulu yang dilaksanakan segera setelah pelaksanaan praktik tertentu selesai. Sementara itu, pemberian umpan balik tertunda (delay feedback) adalah pemberian umpan balik tentang informasi prosedur dan hasil kerja terkait beberapa kinerja praktikum yang dilaksanakan menjelang praktik kinerja keterampilan berikutnya. Di bawah kendalidosen/instruktur, tugas praktik dilaksanakan mengikuti atau sesuai dengan jadwal perkuliahan (pertemuan perminggu), kemudian diberikan um- pan balik langsung atau tertunda sesuai kelompoknya. Penilaian kinerja mahasiswa dilakukan setiap kali praktik dilakukan dan pada akhir pelaksanaan praktikum (sumatif). Permasalahan yang harus dicermati dalam pelaksanaan eksperimen adalah kontrol atau pengendalian yang tepat, sehingga perubahan yang terjadi pada hasil percobaan adalah benar-benar disebabkan oleh adanya perlakuan yang diberikan, dan bukan karena pengaruh faktor-faktor lain. Oleh karena itu, untuk menjamin validitas hasil penelitian, ditempuh langkah-langkah, antara lain: (1) bahwa penentuan kelompok perlakuan dan kontrol dilakukan secara random, sebagaimana yang lazim dilakukan dalam pelaksanaan praktikum pada Jurusan Teknik Elektronika; (2) tidak memberitahukan tentang status subjek percobaan kepada mahasiswa; (3) tidak merubah jadwal perkuliahan; (4) tidak mengganti dosen lain selain yang sudah lazim membina matakuliah tersebut; (5) pengamatan proses pelaksanaan percobaan dilakukan dengan cara tersamar; dan (6) melatih dosen pengasuh mata kuliah (pelaksana) sehingga akan memiliki pemahaman yang sama antardosen tersebut tentang prosedur pelaksanaan percobaan.

Teknikpengumpulan data yang digunakan dalam penelitian terdiri dari: (a) pedoman penilaian (check list) untuk menilai kinerja (prestasi) praktikum mahasiswa yang digunakan oleh dosen/instruktur;dan (b) pedoman observasi, yang digunakan untuk mengamati proses belajar mengajar yang berlangsung di laboratorium. Sebelum 
digunakan untuk pengumpulan data, instrumen penelitian tersebut terlebih dahulu divalidasi oleh peer-revizwer (dosen teknik elektronika FT UNM). Hal tersebut dilakukan untuk menjamin bahwa instrumen penelitian memiliki validitas dan reliabilitas yang baik.

Analisis data penelitian dilakukan dengan teknik analisis deskriptif dalam bentuk nilai rerata, median, mode, standar deviasi, dan analisis inferensial dengan menggunakan uji-t.

\section{HASIL DAN PEMBAHASAN HASIL PENELITIAN}

Seperti dikemukakan pada bagian sebelumnya, dimensi pengukuran tingkat kinerja praktikum mahasiswa terdiri atas kinerja prosedur kerja dan kecepatan menyelesaikan tugas kerja. Kinerja prosedur kerja diukur berdasarkan skor-skor yang diperoleh melalui pengamatan terhadap prosedur kerja dan keberhasilan kerja dengan menggunakan lembar observasi, se- dangkan kecepatan kerja diukur melalui waktu yang dihabiskan untuk menyelesaikan tugas praktikum tersebut. Kegiatan penilaian dilakukan pada saat dan akhir kegiatan praktikum. Berdasarkan hasil penilaian tersebut, selanjutnya kepada mahasiswa diberikan umpan balik oleh dosen/instruktur, baik pada kelompok mahasiswa yang diberi umpan balik langsung (Kelompok A) maupun pada kelompok mahasiswa yang diberi umpan balik tertunda (Kelompok B). Kedua hasil pengukuran tersebut diakumulasikan menjadi skor penilaian terhadap kinerja praktikum mahasiswa.

Untuk memperoleh gambaran mengenai kinerja praktikum mahasiswa, data yang diperoleh selanjutnya diolah dengan statistik deskriptif dalam bentuk harga rerata, median, mode, danstandardeviasi. Hasil analisis deskriptif terhadap kedua kelompok mahasiswa tersebut dapat disajikan pada table ringkasan berikut ini.

Tabel 1. Ringkasan Statistik Hasil Penilaian Kinerja (Prestasi) Praktikum Mahasiswa pada Matakuliah Praktik Elektronika

\begin{tabular}{lcc}
\hline \multirow{2}{*}{ Hasil Statistik Deskriptif } & \multicolumn{2}{c}{ Skor Kinerja Praktikum Mhahasiswa } \\
\cline { 2 - 3 } & Kelompok A & Kelompok B \\
\hline rerata & 83,03 & 78,55 \\
Standar deviasi & 5,51 & 4,79 \\
varians & 30,41 & 22,95 \\
maximum & 94,00 & 84,00 \\
minimum & 70,50 & 69,00 \\
range & 23,50 & 15,00 \\
N & 20 & 19 \\
\hline
\end{tabular}

Berdasarkan hasil analisis yang dinerja praktikum kelompok mahasissajikan pada Tabel 1 di atas, skor kiwa yang diberi umpan balik langsung 
(Kelompok A) dalam mata kuliah Praktek Elektronika adalah: rerata 83,03; median 83,31; mode 85,38; dan standar deviasi5,51. Skor kinerja praktikum kelompok mahasiswa yang diberi umpan balik tertunda (Kelompok B) adalah rerata 78,00 , median 80,00 , dan mode 81 pada skor ideal 100 dengan standar deviasi 4,79. Jika dibandingkan dengan standar ketuntasan kompetensi minimum, ternyata rerata skor kinerja praktikum, baik kelompok mahasiswa yang diberi umpan balik langsung (Kelompok A) maupun kelompok mahasiswa yang diberi umpan balik tertunda (Kelompok B) dapat dikategorikan tinggi.

\section{PENGUJIAN HIPOTESIS}

Pada bagian ini, dilakukan pengujian hipotesis penelitian yang menyatakan "Ada perbedaan kinerja praktikum mahasiswa dalam mata kuliah Praktik Elektronika antara kelompok mahasiswa yang diberi umpan balik langsung (direct feddback) dan kelompok mahasiswa yang diberi umpan balik tertunda (delay feedback)".

Dari hasil analisis data, diperoleh rerata masing-masing kelompok data, simpangan baku masing-masing kelompok, nilai $\mathrm{t}$ hitung serta peluang ralatnya. Agar lebih mudah diinterpretasi, hasil analisis tersebut disusun dalam tabel ringkasan berikut.

Tabel 2. Rangkuman Hasil Analisis t-Test Kinerja Mahasiswa dalam Mata Kuliah Praktik Elektronika

\begin{tabular}{lccccc}
\hline Kelompok & $\mathrm{N}$ & Rerata & $\mathrm{SD}$ & $\mathrm{t}$ hitung & $\mathrm{p}$ \\
\hline Umpan balik langsung & 20 & 83,03 & 5.51 & -3.232 & 0.004 \\
Umpan balik tertunda & 19 & 78,54 & 4.79 & & \\
\hline
\end{tabular}

Berdasarkan hasil analisis uji-t didapatkanhargat-hitung sebesar -3,232, dengan probabilitas 0.004 yang ternyata lebih kecil dari taraf signifikan 5\%. Hal ini menunjukkan bahwa perbedaan mean (rerata) kinerja praktikkum mahasiswa sebesar 5.03 antara kelompokmahasiswa yang diberi umpan balik langsung (immediate feedback) dan kelompok mahasiswa yang diberi umpan balik tertunda (delay feedback) dinyatakan diterima secara signifikan, dan perbedaan tersebut bukan karena kesalahan sampling. Hal ini mengindikasikan bahwa kelompok mahasiswa yang diberi umpan baliklangsung (immediate feedback) memiliki kinerja praktikum yang lebih baik dibandingkan kinerja praktikum kelompok mahasiswa yang diberi umpan balik tertunda (delay feedback). Ini berarti bahwa pemberian umpan balik langsung (immediate feedback) pada kegiatan praktikum lebih efektif daripada pemberian umpan balik tertunda (delay feedback).

Dari segi kualitas proses pembelajaran, berdasarkan penelitian ini terungkapbahwa dengan pemberian umpan balik, baik umpan balik langsung maupun umpan balik tertunda, mahasiswa menunjukkan motivasi yang 
besar untuk belajar dan membangun sikap belajar yang positif. Mahasiswa semakin aktif dan kreatif dalam kegiatan praktikum setelah mendapatkan umpan balik dari dosen/instruktur. Kerja sama antarmahasiswa dalam kelompok semakin terorganisir dengan baik. Mereka dapat memahami tugas masing-masing tanpa harus diperintah sehingga dari segi produk, hasil maupun kualitas penyelesaian tugas sangat memuaskan. Indikatornya adalah bahwa beberapa kelompok praktikum dapat menyelesaikan tugas praktikum melebihi target yang diberikan dengan hasil yang akurat, terutama pada mahasiswa yang diberi umpan balik langsung.

Berdasarkan uraian di atas dapat disimpulkan bahwa umpan balik langsung sangat tepat digunakan dalam suasana pembelajaran praktikum. Namun demikian, tidak tertutup kemungkinan dosen dapat memberikan umpan balik tertunda ketika tidak ada waktu untuk memberikan umpan balik langsung.

\section{PEMBAHASAN}

Pelaksanaan pembelajaran, penilaian hasil belajar, dan umpan balik merupakan tiga komponen yang tidak terpisahkan satu dari yang lainnya. Pemberian umpan balik merupakan salah satu bentuk penguatan dan strategi dalam pembelajaran. Djiwandono (1996), menyatakan bahwa data hasil penilaian menjadi dasar dalam memberikan umpan balik mahasiswa/ siswa, mengenai kemajuan belajar, kelemahan dan keunggulannya sehingga dapat digunakan untuk penyempur- naan atau perbaikan. Memberi umpan balik yang efektif merupakan bagian kunci dari proses pembelajaran, namun tidak semua umpan balik yang diberikan selalu efektif dalam pembelajaran. Oleh karena itu, pengaturan pemberian umpan balik memiliki peran yang sangat penting.

Hasil penelitian ini menunjukkan bahwa pemberian umpan balik segera atau langsung (immediate feedback) lebih efektif dibandingkan pemberian umpan balik tertunda (delay feedback) pada pembelajaran praktikum Elektronika. Hasil penelitian tersebut sejalan dengan temuan Kulik dan Kulik (1988) yang melaporkan bahwa umpan balik langsung lebih efektif daripada umpan balik tertunda. Secara teoretis pun, peningkatan kinerja sangat mungkin dicapai apabila mahasiswa diberikan umpan balik langsung seusai praktik karena mahasiswa dapat segera memproses informasi umpan balik untuk memperbaiki kinerja berikutnya. Oleh karena itu, Allin \& Turnock (2007) menyarankan agar pemberian umpan balik sedekatmungkin dengan peristiwa yang terjadi. Menunda memberi umpan balik dapat menimbulkan tertumpuknya keluhan sehingga akhirnya sulit untuk mengatasinya.

Sebaliknya, pemberian umpan balik yang tertunda dapat memberikan informasi yang tidak sesuai dengan hasil kinerja praktik sebelumnya, sehingga umpan balik cenderung berupa informasi yang menyimpang dari keadaan atau target sasaran yang sebenarnya. Penyimpangan informasi ini perlu dihindari dengan member- 
kan umpan balik berupa pengetahuan tentang hasil praktik kerja secara tepat. Umpan balik tersebut juga sangat menolong jika itu diberikan secara teratur dibanding hanya pada akhir suatu pertemuan ketika mahasiswa hanya mempunyai sedikit peluang untuk bereaksi terhadap umpan balik tersebut.

Umpan balik hanya bermanfaat jika diberi pada waktunya kepada seseorang untuk melakukan sesuatu agar mengenal permasalahan yang dihadapi. Aspek yang paling penting dari proses penilaian di dalam mengangkat prestasi adalah ketetapan umpan balik, seperti dikemukakan oleh Black \& Wiliam (1998). Hal itu perlu difokuskan pada sesuatu yang harus diubah/diperbaiki. Adanya umpan balik dapat memperkecil tingkat kesalahan mahasiswa selama mengikuti praktik di laboratorium. Pada saat praktikum, umpan balik bermanfaat untuk membantu mahasiswa meningkatkan kinerja, menaikkan moral, dan membantu mengembangkan timwork.

Agar umpan balik yang diberikan bermanfaat bagi mahasiswa, seorang dosen/instruktur harus melakukannya secara terencana, kontruktif dan berkelanjutan. Dosen harus dapat menjelaskan tentang umpan balik apa yang ingin diberikan. Mahasiswa perlu mengetahui apakah mereka telah melakukan atau mengerjakan tugastugas praktik dengan benar. Mereka perlu mengetahui hal ini sehingga mereka tetap menjaga untuk melakukannya dengan baik dan benar, dan juga karena umpan balik tersebut akan membuat mereka merasa cukup baik (senang) terhadap diri mereka dan pekerjaan mereka. Umpan balik juga harus bersifat obyektif, deskriptif dan disampaikan pada waktu yang tepat yakni pada saat tujuan pembelajaran masih segar dalam benak mahasiswa.

Umpan balik yang efektif, yaitu harus dapat memberikan bimbingan kepada setiap mahasiswa tentang bagaimana melakukan perbaikan. Black dan Wiliam (1998) menegaskan bahwa setiap mahasiswa harus diberi bantuan dan kesempatan untuk melakukan perbaikan. Dosen tidak hanya memberikan umpan balik yang mencerminkan tentang kinerja yang berkaitan dengan tujuan pembelajaran mahasiswanya, tetapi juga harus dapat memberikan strategi tentang cara yang lebih efektif untuk mencapai tujuan, serta kesempatan untuk menerapkan umpan balik yang diterimanya.

Dampak pengiring dari umpan balik yang diberikan dosen/instruktur, mahasiswa semakin teliti dalam menyelesaikan tugas-tugas yang diberikan. Mahasiswa semakin disiplin dalam mengerjakan tugas-tugas yang diberikan oleh dosen, baik secara lisan maupun tugas-tugas yang telah tercantum dalam jobsheet. Bagi dosen, penerapan umpan balik selama kegiatan praktikum dapat dimanfaatkan untuk memperbaiki dan meningkatkan kualitas proses pembelajaran selanjutnya. Hasil pengamatan juga menunjukkan bahwa dosen/instruktur semakin aktif dalam membimbing dan membantu mahasiswa ketika 
menghadapi kesulitan/masalah dalam menyelesaikan tugas-tugasnya.

Berdasarkan penelitian ini, juga diketahui bahwa baik dosen maupun mahasiswa memberi respon yang sangat positif terhadap penerapan strategi umpanbalik dalam kegiatan praktikum. Dosen pengampu mata kuliah menyatakan bahwa pemberian umpan balik dapat membantu mahasiswa untuk fokus terhadap pekerjaan/ tugas. Dosen tidak kehilangan informasi tentang perkembangan kemampuan individu maupun kelompok mahasiswa setiap kali praktikum karena kegiatan mahasiswa direkam atau dinilai secara komprehensip dan berkelanjutan.

Sesuai dengan temuan dan pembahasan hasil penelitian ini, strategi umpan balik yang tepat untuk diterapkan pada pemebelajaran praktikkum elektronika adalah jenis umpan balik langsung (immediate feedback), yakni suatu umpan balik yang diberikan segera setelah kegiatan praktikkum selesai. Namun demikian, dapat saja seorang dosen memberikan umpan balik tertunda ketika tidak ada waktu untuk memberikan umpan balik langsung.

\section{KESIMPULAN}

Berdasarkan hasil penelitian dan pembahasan yang telah dipaparkan, dapat dirumuskan beberapa kesimpulan sebagai berikut.

Rerata skor kinerja (prestasi) praktikum, baik kelompok yang diberi umpan balik langsung (immediate feedback) maupun kelompok yang diberi umpan balik tertunda (delay feedback) dapat dikategorikan tinggi. Hasil penelitian menunjukkan bahwa terdapat perbedaan kinerja praktikum mahasiswa dalam mata kuliah Praktik Elektronika antara kelompok mahasiswa yang diberi umpan balik langsung (immediatefeddback) dan kelompok mahasiswa yang diberi umpan balik tertunda (delay feedback). Hal ini berarti bahwa kinerja praktikum mahasiswa yang mendapat umpan balik langsung lebih unggul dibandingkan dengan kinerja praktikum mahasiswa yang diberi umpan balik tertunda. Penerapan strategi umpan balik dapat meningkatkan kualitas proses dan hasil pembelajaran mata kuliah Praktik Elektronikapada Jurusan Teknik Elektronika Fakultas Teknik Universitas Negeri Makassar.

Implikasi dari hasil penelitian ini dapat menjadi masukan bagi dosen pengasuh mata kuliah praktikum yang lainnya bahwa pemberian umpan balik langsung lebih memberikan dampak bagi kinerja praktikum mahasiswa sehingga dapat menjadi salah satu strategi untuk meningkatkan kualitas pembelajaran dalam matakuliah yang diasuhnya.

\section{UCAPAN TERIMA KASIH}

Penelitian ini dapat berlangsung dengan baik, atas dukungan beberapa pihak. Oleh karena itu, pada kesempatan ini, saya ucapkan terima kasih yang sebesar-besarnya kepada Kepala Laboratorium dan Staf PT Elektronika UNM Makassar dan juga kepada mahasiswa yang terlibat dalam penelitian ini. Di samping itu, juga saya ucapkan banyak terima kasih kepada 
Dewan Redaksi Jurnal Cakrawala Pendidikan, khususnya Bapak Prof. Pardjono, Ph.D., yang telah memberikan saran yang sangat berharga dalam perbaikan artikel ini. Semoga Allah SWT memberkati semua pihak yang telah membantu penulisan artikel ini.

\section{DAFTAR PUSTAKA}

Adams, B. J., \& Fields, L. 1999. "Effects of Unreinforced Conditional Selection Trainings, Multiple $\mathrm{Ne}$ gative Comparison Training, and Feedback on Equivalencenclass Formation". Journal of The Psychological Record, Vol. 49, 685-702.

Allin, L. \& Turnock, C. 2007. Assessing Student Performance in WorkBased Learning. www.practicebasedlearning.org. Diunduh 20 Mei 2010.

Anderson, D. I., Magill, R. A., \& Seklya, H. 2001. Motor Learning as a Function of KR Schedule and Characteristics of Task-Intrinsic Feedback. Journal of Motor Behavior, Vol.33, 59-66.

Berk, R.A. 1986. Performance Assessment, Methods, $\mathcal{E}$ Applications. Lonon: Hopkins University Press.

Black, P. \& Wiliam, D. 1998. "Assessment and Classroom Learning". Journal Assessment in Education, Vol. 5, pp. 7-73.
Bloxham, S., Boyd, P. 2007. Developing Effective Assessment in Higher Education. New York: Open University Press.

Beck, F. W., \& Lindsey, J. D. 1979. "Effects of Immediate Information Feedback and Delayed Information Feedback on Delayed Retention". Journal of Educational Research, vol.72, 283-284.

Clarke, S. 2005. Formative Assessment in Action Weaving the Elements Together. London: Hodder $\mathrm{Mu}-$ rray.

Dihoff, R. E., Brosvic, G M., \& Epstein, M. L. The Role of Feedback during Academic Testing: the Delay Retention Effect Revisited. Lawrenceville. Department of Psychology, Rider University. http//www.epsteineducation.com.

Diunduh 20 Mei 2010.

Epstein, M. L., Epstein, B. B., \& Brosvic, G. M. 2001. "Immediate Feedback during Academic Testing". Psychological Reports, Vol. 88, 889-894.

Hanna, G. H. 1976. “Effects of Total \& Partial Feedback in MultipleChoice Testing upon Learning". The Journal of Educational Research, Vol. 69, 202-205.

Irons, A. 2008. Enhancing Learning through Formative Assessment and Feedback. USA and Canada: 
Routledge Taylor \& Francis eLibrary.

Joughin, G. 2009. Assessment, Learning and Judgement in Higher Education. Australia: CEDIR, University of Wollongong.

Kippel,G.M. 1974. “Information Feedback, Need Achievement and Retention". The Journal of Educational Research, Vol. 60, 256260.

Kulik, J. A., \& Kulik, C. C. 1988. "Timing of Feedback and Verbal Learning". Review of Educational Research (Journals Online), Vol. 58, 79-97.

Mutch, A. 2003. “Exploring the Practice of Feedback to Students". Active Learning in Higher Education, Vol. 4(1): 24-38.

Orrell, J. 2006. Feedback on Learning Achievement:Rhetoric and Reality, Teaching in Higher Education, Vol. 11(4): 441-56.

Popham, W.J. 2004. Classroom Assessment, What Teachers Need to Know. Boston: Allyn Bacon.

Newman, M. I., Williams, R. G., \& Hiller, J. H. 1974. Delay of Information Feedback in an Applied Setting: Effects of Initially Learned and Unlearned Items". Journal of Experimental Education, Vol. 42, 55-59.
Robin, A. L. 1978. “The Timing of Feedback in Personalized Instruction". Journal of Personalized Instruction, Vol. 3, 81-87.

Stevens, D.D., Levi, A. 2005. Introduction to Rubrics: an Assessment Tool to Save Grading Time, Convey Effective Feedback, and Promote Student Learning. Canada: Stylus Publishing, LLC.

Tulgan, B. 1999. FAST Feedback. Massachusetts: HRD Press, Inc.

Weaver, M.R. 2006. “Do Students Value Feedback? Student Perceptions of Tutors' Written Responses". Assessment and Evaluation in Higher Education, Vol. 31(3): 79-94.

Webb, J. M., Stock, W. A., \& McCarthy, M. T. 1994. "The Effects of Feedback Timing on Learning Facts: The Role of Response Confidence". Contemporary Educational Psychology, vol.19, 251-265. 